\title{
APLIKASI PEREKRUTAN KARYAWAN MENGGUNAKAN METODE TOPSIS BERBASISKAN WEB PADA PT. SMESCO INDONESIA
}

\author{
Muhammad Andri Imawan'), Margi Cahyanti'), Moch. Wisuda Sardjono ${ }^{3)}$, dan Ericks Rachmat Swedia ${ }^{4)}$ \\ ${ }_{1,2,3,4}$ Fakultas Teknologi Informasi dan Ilmu Komputer Universitas Gunadarma \\ Jl. Margonda Raya No. 100, Depok 16424, Jawa Barat \\ E-mail: andriimawan97@gmail.com ${ }^{1)}$, margi@staff.gunadarma.ac.id ${ }^{2)}$, moch_wisuda@staff.gunadarma.ac.id ${ }^{3)}$, \\ ericks_rs@staff.gunadarma.ac.id ${ }^{4)}$
}

\begin{abstract}
ABSTRAK
SMESCO Indonesia merupakan sebuah perusahaan yang bergerak dalam bidang usaha retail. Perusahaan ini membutuhkan sistem pengambilan keputusan dalam penerimaan calon karyawan kontrak setiap tahun di bidang IT Support karena selama ini mengalai kesulitan dalam memproses perhitungan penerimaan calon karyawan. Sebelumnya proses penilaian calon karyawan pada SMESCO Indonesia dilakukan dengan cara semi komputerisasi dengan kriteria nilai tertinggi yang terpilih, belum menggunakan metode perangkingan bobot pada setiap kriteria penilaian, dan proses perhitungan masih dilakukan menggunakan microsoft excel, sehingga proses administrasi berkas tidak terpusat, dikerjakan oleh pengguna yang berbeda di komputernya masing-masing yang dapat mengakibatkan data hilang dan menjadi sulit ditemukan karena tersebar di beberapa komputer. Penelitian ini bertujuan untuk mengimplementasikan program aplikasi Decision Support Systems (DSS) berbasis web yang dapat membantu Human Resources Departement (HRD) SMESCO Indonesia dalam proses penilaian terhadap calon karyawan dengan cepat dan akurat. Terdapat beberapa metode yang dapat digunakan untuk pengambilan keputusan dalam penentuan perekrutan karyawan, salah satunya adalah menggunakan metode TOPSIS (Techinique for Order Preference by Similarity to Ideal Solution). Metode ini digunakan dalam perhitungan perekrutan karyawan karena metode ini memiliki hasil penilaian yang objektif, konsepnya yang mudah dipahami dan memiliki waktu komputasi yang efisien. Aplikasi Decision Support Systems (DSS) dengan metode TOPSIS yang diimplementasikan ini berisi data karyawan, kriteria data penilaian, kriteria data alternatif dan kriteria pembobotan data.
\end{abstract}

Kata Kunci: Sistem Penunjang Keputussan, TOPSIS, Aplikasi Web, Perekrutan Karyawan

\section{PENDAHULUAN}

Perkembangan teknologi informasi yang semakin pesat di era globalisasi saat ini tidak bisa dihindari lagi pengaruhnya terhadap dunia perkantoran. Salah satu teknologi informasi seperti komputer dapat mempermudah pekerjaan seseorang dalam mengakses informasi dalam berbagai bidang, salah satunya di bidang perkantoran. Teknologi komputer menjadikan setiap pekerjaan dapat diselesaikan dengan cepat, tepat, dan akurat, sehingga pekerjaan lebih efektif dan efisien (Putri, 2018). Tuntutan global menuntut dunia perkantoran untuk senantiasa menyesuaikan perkembangan teknologi terhadap usaha dalam peningkatan mutu administrasi perkantoran, terutama penyesuaian penggunaan teknologi informasi dan komunikasi bagi dunia perkantoran (Sunalia, 2017). Salah satu perusahaan di Jakarta Selatan, yaitu SMESCO Indonesia membutuhkan sistem pengambilan keputusan mengenai penerimaan calon karyawan kontrak di bidang IT yang berlangsung setiap tahun.

Sistem pendukung keputusan merupakan suatu perangkat sistem yang mampu memecahkan masalah secara efisien, efektif, yang bertujuan untuk membantu pengambilan keputusan dalam memilih berbagai alternatif (Irfan, 2012). Keputusan yang ditawarkan oleh sistem pendukung keputusan, cenderung cepat dan secara kuantitatif merupakan pilihan terbaik berdasarkan tingkat kepentingan/bobot kriteria yang diberikan oleh pihak manajemen sebagai pengambil keputusan (Kusumadewi, 2006). Penelitian membuat sistem pendukung keputusan pernah dilakukan dengan menggunakan Multiple Attribute Decision Making (MADM) pada tahun 2015, yang mampu menetapkan kriteria alternatif terbaik dari sejumlah alternatif berdasarkan beberapa kriteria tertentu (Karmila, 2017).

Terdapat beberapa metode yang dapat digunakan untuk pengambilan keputusan dalam penentuan perekrutan karyawan, salah satunya adalah menggunakan metode TOPSIS (Techinique for Order Preference by Similarity to Ideal Solution). Metode ini berdasarkan pada konsep perangkingan alternatif terpilih yang ditentukan tidak hanya memiliki jarak terpendek dari solusi ideal positif tetapi juga memiliki jarak terpanjang dari solusi ideal negatif (Satriawaty, 2015). Konsep ini banyak digunakan untuk menyelesaikan masalah keputusan secara praktis. Dengan menggunakan metode perangkingan ini penilaian akan lebih tepat karena didasarkan pada nilai kriteria dan bobot yang sudah ditentukan sehingga akan mendapatkan hasil yang lebih akurat (Irvan, 2017).

Penelitian menggunakan metode TOPSIS ini telah diterapkan pada pemilihan asisten laboratorium komputer pada STMIK Widya Cipta Dharma di tahun 2018. Kriteria 
yang digunakan dalam seleksi asisten laboratorium diantaranya : Kemampuan Mengajar, Penguasaan Materi, Wawancara, Tanggung Jawab dan Disiplin. Bobot yang digunakan untuk masing-masing kriteria adalah 25, 15, 5, 25 dan 30 (Harpad, B dan Salmon, 2018). Penelitian tentang metode TOPSIS telah dilakukan pula untuk sistem penerimaan pegawai pada SMA Al-Washliyah Tanjung Morawa. Kriteria yang digunakan sebanyak empat kriteria diantarnya : Test IPK, Test Psikologi, Test Toefl dan Test Wawancara. Bobot nilai dari masing-masing kriteria adalah 25, 25, 10 dan 40 (Sriani, S dan Putri, 2018).

Proses penilaian calon karyawan pada SMESCO Indonesia selama ini dilakukan dengan cara semi komputerisasi dengan kriteria nilai tertinggi yang terpilih, belum menggunakan metode perangkingan bobot pada setiap kriteria penilaian, dan proses perhitungan masih dilakukan menggunakan microsoft excel, sehingga proses administrasi berkas tidak terpusat, dikerjakan oleh pengguna yang berbeda di komputernya masing-masing yang dapat mengakibatkan data hilang dan menjadi sulit ditemukan karena tersebar di beberapa komputer. SMESCO Indonesia memerlukan sebuah sistem terpadu untuk mempermudah proses pengolahan perekrutan karyawan menggunakan metode sistem pengambilan keputusan yang dapat menilai berdasarkan bobot pada setiap kriteria penilaian sehingga dengan adanya sistem ini diharapkan dapat membantu manajemen dalam memilih karyawan yang sesuai dengan kebutuhan.

\section{RUANG LINGKUP}

Pada penelitian ini dibahas mengenai cara rancang dan membuat sistem pendukung keputusan yang memudahkan SMESCO Indonesia dalam menentukan calon karyawan terbaik dengan menggunakan metode TOPSIS berbasis web.

Berdasarkan perumusan masalah yang telah ditentukan, maka dalam penelitian ini dibatasi pada penentuan kriteria penilaian calon karyawan dan pembobotan di setiap kriteria penilaian. Adapun kriteria penilaian yang digunakan adalah membuat aplikasi dengan nilai bobot sebesar 2, membuat cyber security untuk aplikasi dengan nilai bobot 3 , merancang arsitektur dengan nilai bobot 3 , merancang infrastruktur dengan nilai bobot 1 , instalasi dan pemeliharaan server dengan nilai bobot 1, jaringan LAN / WAN dengan nilai bobot 1 .

Penelitian ini bertujuan merancang sistem pendukung keputusan yang dapat digunakan untuk membantu menentukan karyawan terbaik menggunakan metode TOPSIS berbasis web.

\section{BAHAN DAN METODE}

Langkah-langkah dalam memutuskan perekrutan calon karyawan PT. SMESCO Indonesia dibahas pada bagian ini dengan Decision Support System (DSS) menggunakan menggunakan metode Technique for Order Preference by Similarity to Ideal Solution (TOPSIS)

\subsection{Desicion Support Systems (DSS)}

Pada dasarnya Sistem Pendukung Keputusan adalah merupakan pengembangan lebih lanjut dari sistem informasi manajemen terkomputerisasi yang dirancang sehingga bersifat interaktif bagi pemakainya. Sifat interaktif ini dimaksudkan untuk memudahkan integrasi antara berbagai komponen dalam proses pengambilan keputusan seperti prosedur, kebijakan, teknik analisis, serta pengalaman dan wawasan manajerial yang berguna untuk membentuk suatu kerangka keputusan yang bersifat fleksibel (Kusumadewi, 2006).

\subsection{Metode Technique for Order Preference by Similarity to Ideal Solution (TOPSIS)}

Hwang dan Zeleny mendefinisikan TOPSIS merupakan sebuah konsep dimana alternatif terpilih yang terbaik tidak hanya memiliki jarak terpendek dari solusi ideal positif, namun juga memiliki jarak terpanjang dari solusi ideal negatif (Karmila, 2017). TOPSIS banyak digunakan pada beberapa model MADM untuk menyelesaikan masalah keputusan secara praktis karena memiliki konsep yang sederhana dan mudah dipahami, komputasinya efisien, dan memiliki kemampuan untuk mengukur kinerja relatif dari alternatif - alternatif keputusan dalam bentuk matematis yang sederhana. Secara umum, prosedur TOPSIS mengikuti langkahlangkah sebagai berikut:

1. Membuat matriks bobot keputusan yang ternormalisasi. TOPSIS membutuhkan rating kinerja setiap alternatif $A_{i}$ pada setiap bobot $r_{i j}$ yang ternormalisasi, yaitu :

$$
r_{i j}=\frac{X_{i j}}{\sqrt{\sum_{i=1}^{m} X_{i j}}}
$$

dimana :

$\mathrm{X}_{\mathrm{ij}}=$ Matriks data input penilaian calon karyawan dengan $\mathrm{i}=1,2,3, \ldots \mathrm{m}, \mathrm{j}=1,2,3, \ldots \mathrm{n}$.

$\mathrm{r}_{\mathrm{ij}}=$ Matriks normalisasi kriteria penilaian dengan $\mathrm{i}=1,2, \ldots \mathrm{m}$.

$\mathrm{m}=$ Jumlah calon karyawan.

$\mathrm{n}=$ Jumlah kriteria penilaian.

Solusi ideal positif $\mathrm{A}^{+}$dan solusi ideal negatif $\mathrm{A}^{-}$ dapat ditentukan berdasarkan rangking bobot ternormalilasi $\left(\mathrm{y}_{\mathrm{ij}}\right)$ :

$$
\begin{aligned}
& y_{i j}=w_{j} r_{i j} \\
& A^{+}=\left(y_{1}^{+}, y_{2}^{+}, \ldots y_{n}^{+}\right) \\
& A^{-}=\left(y_{1}^{-}, y_{2}^{-}, \ldots y_{n}^{-}\right) \\
& y_{j}^{+}=\max y_{i j} \\
& y_{j}^{-}=\min y_{i j}
\end{aligned}
$$

dimana :

$r_{i j}=$ Matriks normalisasi kriteria penilaian dengan $i=1,2,3, \ldots \mathrm{m}, \mathrm{j}=1,2,3, \ldots \mathrm{n}$.

$\mathrm{y}_{\mathrm{ij}}=$ Matriks bobot normalisasi kriteria 
penilaian dengan $\mathrm{i}=1,2,3, \ldots \mathrm{m}$,

$$
\mathrm{j}=1,2,3, \ldots . \mathrm{n}
$$

$\mathrm{W}_{\mathrm{j}}=$ Bobot dengan $\mathrm{j}=1,2,3, \ldots \mathrm{n}$.

$\mathrm{m}=$ Jumlah calon karyawan.

$\mathrm{n}=$ Jumlah kriteria penilaian.

2. Menghitung jarak alternatif.

Jarak antara aternatif $A_{i}$ dengan solusi ideal positif dirumuskan:

$$
D_{i}^{+}=\sqrt{\sum_{j=1}^{n}\left(y_{i}^{+}-y_{i j}\right)^{2}}
$$

Jarak antara alternatif $\mathrm{A}_{\mathrm{i}}$ dengan solusi ideal negatif dirumuskan:

$$
D_{i}^{-}=\sqrt{\sum_{j=1}^{n}\left(y_{i j}-y_{i}^{-}\right)^{2}}
$$

3. Menentukan nilai preferensi.

Nilai preferensi untuk setiap alternatif $\left(\mathrm{V}_{\mathrm{i}}\right)$ diberikan

$$
V_{i}=\frac{D_{i}^{-}}{D_{i}^{-}+D_{i}^{+}}
$$

Nilai $\mathrm{V}_{\mathrm{i}}$ yang lebih besar menunjukan bahwa alternatif $\mathrm{A}_{\mathrm{i}}$ lebih dipilih.

\section{PEMBAHASAN}

Dalam tahap ini akan dibahas perhitungan dengan menggunakan metode TOPSIS dan perancangan sistem perekrutan PT. SMESCO Indonesia.

\subsection{Perhitungan Dengan Metode TOPSIS}

Terdapat enam kriteria penilaian untuk calon karyawan di SMESCO Indonesia, yaitu : penilaian membuat aplikasi, membuat cyber security, merancang arsitektur, merancang infrastruktur, instalasi dan pemeliharaan server dan jaringan lan / wan. Dengan skala perhitungan : 1 = sangat buruk, $2=$ buruk, $3=$ baik, $4=$ sangat baik, diasumsikan ada 3 calon pegawai A, B, C. Calon A mendapatkan penilaian membuat aplikasi dengan nilai 1, membuat cyber security untuk aplikasi dengan nilai 1 , merancang arsitektur dengan nilai 3, merancang infrastruktur dengan nilai 3 , instalasi dan pemeliharaan server dengan nilai 3, jaringan lan / wan dengan nilai 3 .

Calon B mendapatkan penilaian membuat aplikasi dengan nilai 4 , membuat cyber security untuk aplikasi dengan nilai 3, merancang arsitektur dengan nilai 3, merancang infrastruktur dengan nilai 3, instalasi dan pemeliharaan server dengan nilai 1 , jaringan lan / wan dengan nilai 1. Calon $\mathrm{C}$ mendapatkan penilaian membuat aplikasi dengan nilai 2, membuat cyber security untuk aplikasi dengan nilai 4 , merancang arsitektur dengan nilai 2 , merancang infrastruktur dengan nilai 2, instalasi dan pemeliharaan server dengan nilai 3, jaringan lan / wan dengan nilai 3 . Tabel penilaian setiap calon dapat dilihat pada tabel 1 dan tabel 2 .
Tabel 1. Penilaian Calon Karyawan

\begin{tabular}{|c|c|c|c|}
\hline ID & $\begin{array}{c}\text { Membuat } \\
\text { Aplikasi }\end{array}$ & $\begin{array}{c}\text { Membuat Cyber } \\
\text { Security }\end{array}$ & $\begin{array}{c}\text { Merancang } \\
\text { Arsitektur }\end{array}$ \\
\hline A & 1 & 1 & 3 \\
\hline B & 4 & 3 & 3 \\
\hline C & 2 & 4 & 2 \\
\hline
\end{tabular}

Tabel 2. Penilaian Calon Karyawan

\begin{tabular}{|c|c|c|c|}
\hline ID & $\begin{array}{c}\text { Merancang } \\
\text { Infrastruktur }\end{array}$ & $\begin{array}{c}\text { Instalasi dan } \\
\text { Pemeliharaan } \\
\text { Server }\end{array}$ & $\begin{array}{c}\text { Jaringan } \\
\text { LAN / } \\
\text { WAN }\end{array}$ \\
\hline A & 3 & 3 & 3 \\
\hline B & 3 & 1 & 1 \\
\hline C & 2 & 3 & 3 \\
\hline
\end{tabular}

Keterangan : skala 1=sangat buruk, $2=$ buruk, $3=$ baik, $4=$ sangat baik.

Setiap penilaian memiliki bobot yang ditentukan oleh pakar, sebagai berikut: membuat aplikasi mempunyai nilai bobot 2, membuat cyber security untuk aplikasi mempunyai nilai bobot 3, merancang arsitektur mempunyai nilai bobot 3, merancang infrastruktur mempunyai nilai bobot 1 , instalasi dan pemeliharaan server mempunyai nilai bobot 1 , jaringan lan / wan mempunyai nilai bobot 1 , sehingga matriks $X$ dan bobot $\mathrm{W}$ menjadi sebagai berikut :

$$
X=\left[\begin{array}{llllll}
1 & 1 & 3 & 3 & 3 & 3 \\
4 & 4 & 3 & 3 & 1 & 1 \\
2 & 4 & 2 & 2 & 3 & 3
\end{array}\right]
$$

$$
\mathrm{W}=(2 ; 3 ; 3 ; 1 ; 1 ; 1)
$$

Perhitungan kolom ke-1 berdasarkan persamaan (1) :

$\begin{array}{lll}\mathrm{r}_{11}= & \frac{1}{\sqrt{1^{2}+4^{2}+2^{2}}}=0.2182 \\ \mathrm{r}_{12}= & \frac{4}{\sqrt{1^{2}+4^{2}+2^{2}}}=0.8729 \\ \mathrm{r}_{13}= & \frac{2}{\sqrt{1^{2}+4^{2}+2^{2}}}=0.4364\end{array}$

Rumus perhitungan kolom ke-2 sampai ke-6 sama dengan contoh perhitungan kolom ke-1, sehingga diperoleh matrik ternormalisasi $r$ :

$$
r=\left[\begin{array}{llllll}
0,2182 & 0,1741 & 0,6396 & 0,6396 & 0,6882 & 0,6882 \\
0,8729 & 0,6963 & 0,6396 & 0,6396 & 0,2294 & 0,2294 \\
0,4364 & 0,6963 & 0,4264 & 0,4264 & 0,6882 & 0,6882
\end{array}\right]
$$

Langkah selanjutnya adalah membuat matriks keputusan $\mathrm{y}_{i j}$ yang ternormalisasi dalam bobot $\mathrm{w}$, berdasarkan persamaan (2). Perhitungan kolom ke-1 :

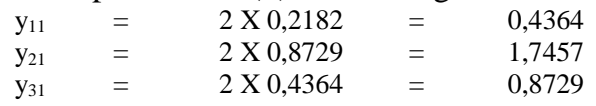


Rumus perhitungan kolom ke-2 sampai ke-6 sama dengan contoh perhitungan kolom ke-1 sehingga diperoleh matrik ternormalisasi $y$.

$$
y=\left[\begin{array}{llllll}
0,4364 & 0,5222 & 1,9188 & 0,6396 & 0,6882 & 0,6882 \\
1,7457 & 2,0889 & 1,9188 & 0,6396 & 0,2249 & 0,2294 \\
0,8729 & 2,0889 & 1,2792 & 0,4264 & 0,6882 & 0,6882
\end{array}\right]
$$

Menentukan matriks solusi ideal positif dan solusi ideal negatif dengan persamaan (3) dan (4) :

$Y+j=(1,74572,08891,91880,63960,68820,6882)$

$Y-j=(0,43640,52221,27920,42640,22940,2294)$

Perhitungan selanjutnya adalah menghitung $\mathrm{D}^{+}$yang merupakan jarak alternatif matriks solusi ideal positif dengan matriks $\mathrm{y}$, dan menghitung $\mathrm{D}^{-}$yang merupakan jarak solusi ideal negatif dengan matriks $\mathrm{y}$.

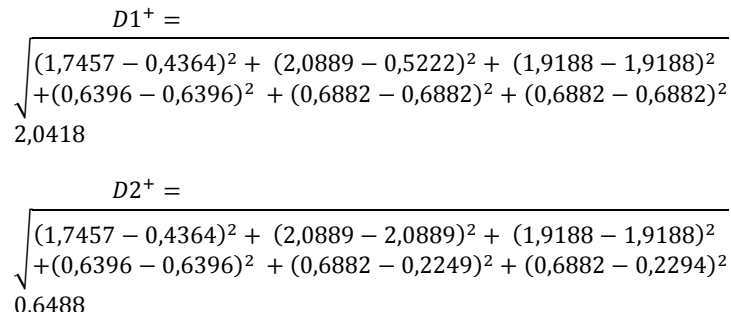

$$
\begin{aligned}
& D 3^{+}= \\
& \begin{array}{l}
(1,7457-0,8729)^{2}+(2,0889-2,0889)^{2}+(1,9188-1,2792)^{2} \\
+(0,6396-0,4264)^{2}+(0,6882-0,6882)^{2}+(0,6882-0,6882)^{2}
\end{array} \\
& 1,103 \\
& \quad D 1^{-}= \\
& \sqrt{\begin{array}{l}
(0,4364-0,4364)^{2}+(0,5222-0,5222)^{2}+(1,9188-1,2792)^{2} \\
+(0,6396-0,4264)^{2}+(0,6882-0,2294)^{2}+(0,6882-0,2294)^{2}
\end{array}} \\
& 0,9357
\end{aligned}
$$

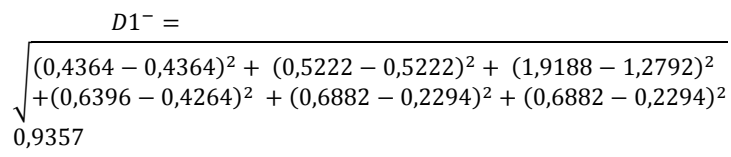

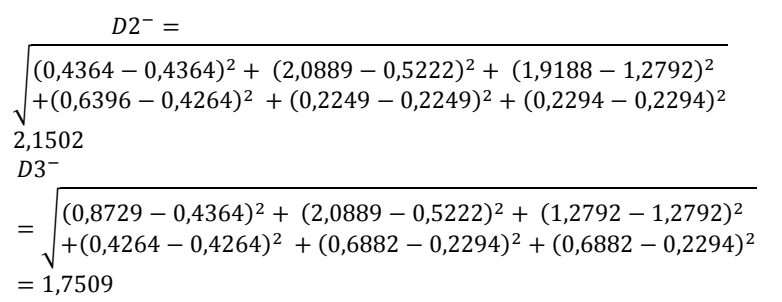

$$
D^{+}=\left[\begin{array}{l}
2,0418 \\
0,6488 \\
1,1030
\end{array}\right] \quad D^{-}=\left[\begin{array}{l}
0,9357 \\
2,1502 \\
1,7509
\end{array}\right]
$$

Menghitung nilai preferensi untuk semua alternatif

$$
\begin{aligned}
& \mathrm{V} 1=\frac{0,9357}{0,9357+2,0418}=0,3143 \\
& \mathrm{~V} 2=\frac{2,1502}{2,1502+0,6488}=0,7682 \\
& \mathrm{~V} 3=\frac{1,7509}{1,7509+1,1030}=0,6135
\end{aligned}
$$

Sehingga diperoleh :

$$
\mathrm{V}=\left[\begin{array}{l}
0,3143 \\
0,7682 \\
0,6135
\end{array}\right]\left[\begin{array}{l}
A \\
B \\
C
\end{array}\right]
$$

Hasil perangkingan diurutkan dari nilai $\mathrm{V}$ tertinggi, sehingga calon pegawai B mendapatkan rangking 1 , calon pegawai $\mathrm{C}$ mendapatkan rangking 2 , dan calon pegawai $\mathrm{A}$ mendapatkan rangking 3 .

$$
\text { Rangking }=\left[\begin{array}{l}
0,7682 \\
0,6135 \\
0,3143
\end{array}\right]\left[\begin{array}{l}
B \\
C \\
A
\end{array}\right]
$$

\subsection{Perancangan Sistem Perekrutan Karyawan di SMESCO Indonesia Menggunakan TOPSIS}

Untuk merancang sistem diperlukan pembuatan database dan tabel. Database SPKKU dengan tabel admin digunakan untuk menyimpan data admin, tabel alternatif digunakan untuk menyimpan data penamaan pemilihan, tabel bobot digunakan untuk menyimpan data nilai bobot, tabel hasil digunakan untuk menyimpan data perhitungan hasil, tabel jarak solusi ideal digunakan untuk menyimpan data Jarak Solusi Ideal, tabel pemilihan digunakan untuk menyimpan data nama calon karyawan, tabel matrik $\mathrm{R}$ digunakan untuk menyimpan data matrik $\mathrm{R}$, tabel matrik Y digunakan untuk menyimpan data matrik $Y$, tabel user digunakan untuk menyimpan data nilai ideal, tabel rangking digunakan untuk menyimpan data ranking, rancangan tabel terlihat pada gambar 1 class diagram berikut 


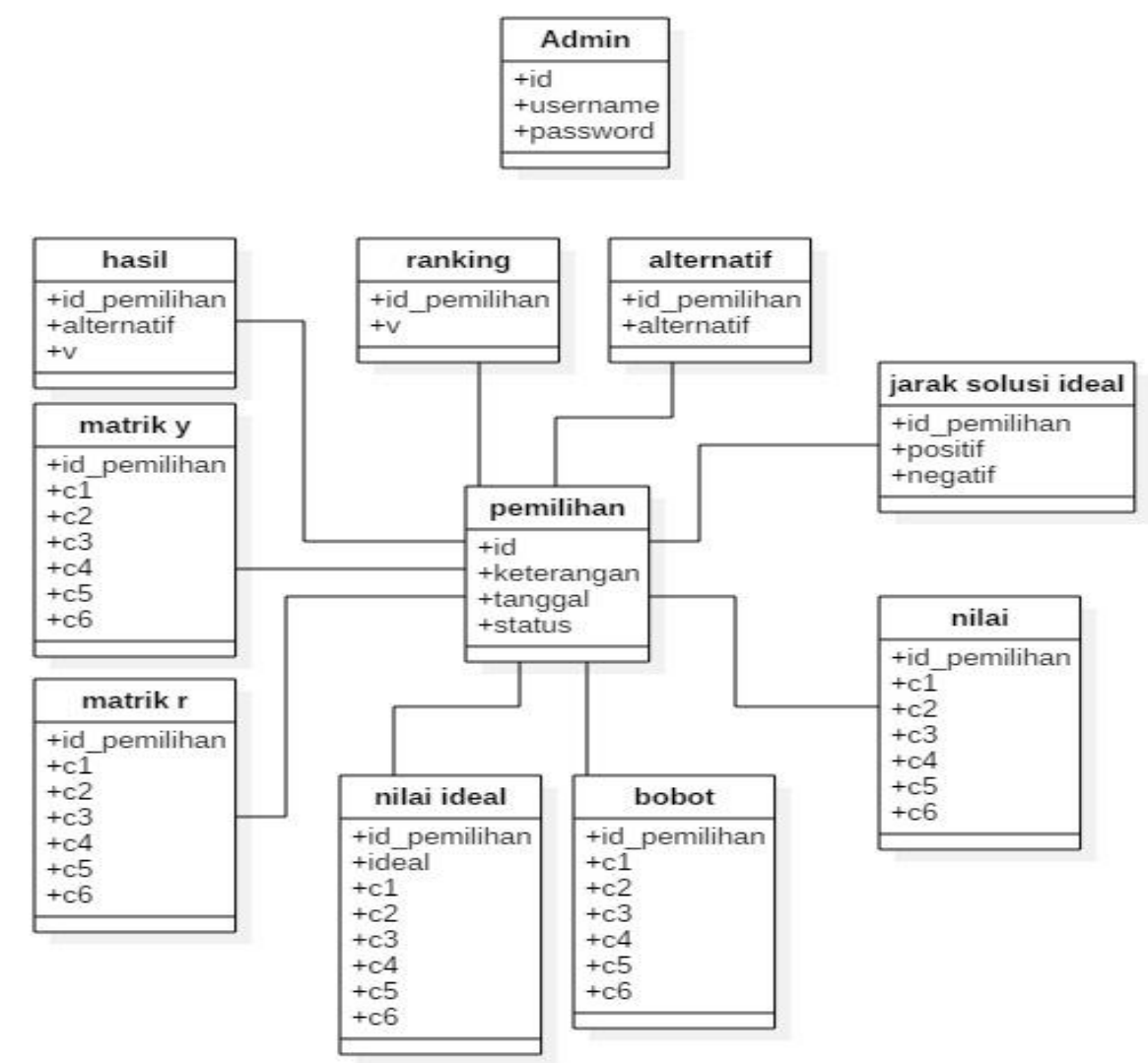

Gambar 1. Class Diagram Database SPKKU

\subsection{Perancangan Aplikasi berbasis Web}

Pada gambar 2, menampilkan Halaman Login untuk digunakan user pertama kali akses aplikasi. Ketika ingin menggunakan aplikasi ini, pengguna diharuskan menginputkan username dan password yang telah diberikan, kemudian klik tombol Login. Jika sesuai maka akan menampilkan Halaman SPK seperti yang tampil pada gambar 3 .

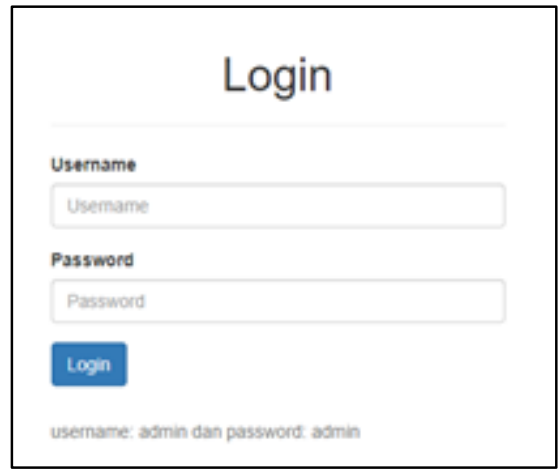

Gambar 2. Halaman Login

Gambar 3, menampilkan Halaman SPK yang dapat digunakan setelah pengguna berhasil login. Pada halaman ini, pengguna diberikan informasi kriteria karyawan yang dibutuhkan oleh perusahaan. Setelah mengetahui kriteria karyawan yang dibutuhkan, pengguna dapat meng-klik tombol Mulai untuk menampilkan halaman berikutnya yaitu Halaman Informasi Pemilih, seperti pada gambar 4.

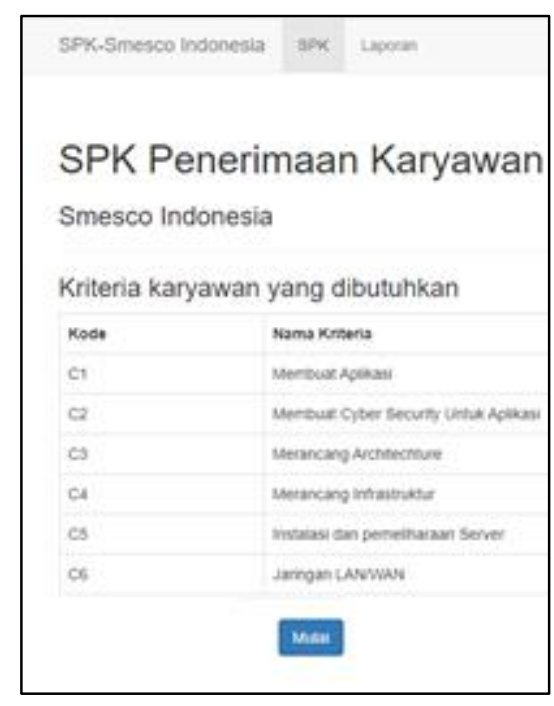

\section{Gambar 3. Halaman SPK}

Halaman Informasi Pemilihan yang ditampilkan pada gambar 4, digunakan untuk pengisian Judul Pemilihan Karyawan. Setelah mengisikan Judul Pemilihan, klik tombol Lanjutkan, untuk melakukan tahapan berikutnya 
yaitu pemilihan calon karyawan seperti tampilan pada gambar 5.

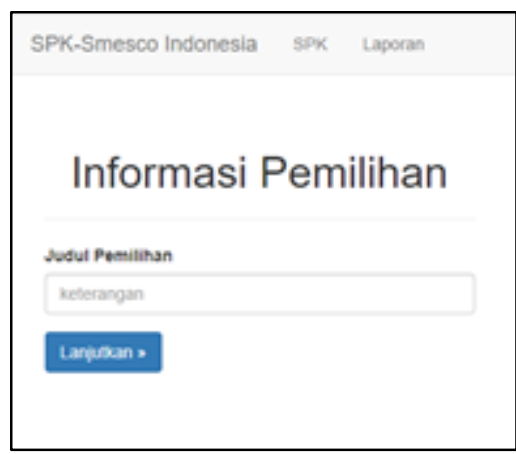

\section{Gambar 4. Halaman Informasi Pemilihan}

Pada Halaman Pemilihan Calon Karyawan, yang ditampilkan pada gambar 5, pengguna dapat memilih calon karyawan dengan menginputkan nama calon karyawan. Di halaman ini terdapat tombol Tambah, untuk menambahkan nama calon karyawan, tombol Hapus untuk menghapus data calon karyawan dan tombol Nilai, untuk mengisikan penilaian terhadap calon karyawan berdasarkan kriteria yang telah diinformasikan sebelumya pada gambar 3 .

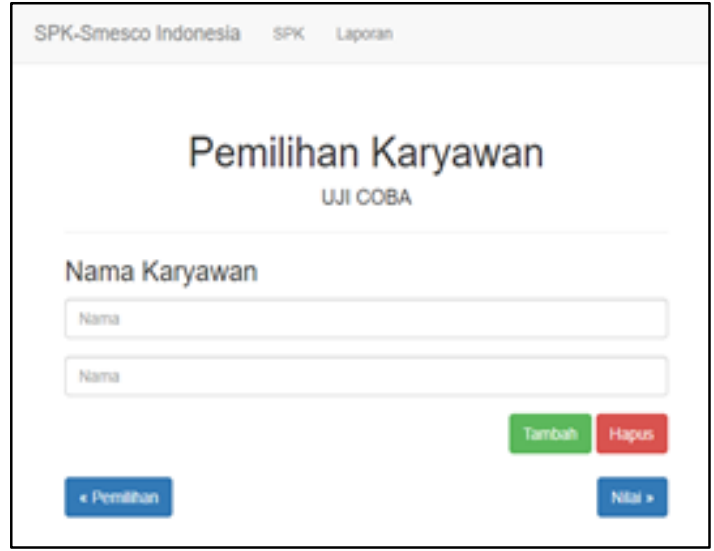

\section{Gambar 5. Halaman Pemilihan Karyawan}

Pada gambar 6, menampilkan Halaman Input Penilaian calon karyawan berdasarkan kriteria yang telah ditentukan sebelumnya. Pengguna mengisikan penilaian ujian dari setiap calon karyawan yang dipilih dengan isian pada kriteria 1 (C1), kriteria 2 (C2), kriteria 3 (C3), kriteria 4 (C4), kriteria 5 (C5) dan kriteria 6 (C6). Adapun isian penilaian berupa angka 1 = Sangat Buruk, $2=$ Buruk, $3=$ Baik dan $4=$ Sangat Baik. Setelah selesai mengisikan penilaian, pengguna meng-klik tombol Bobot untuk memberikan nilai bobot setiap kriteria seperti yang ditampilkan pada gambar 7 .

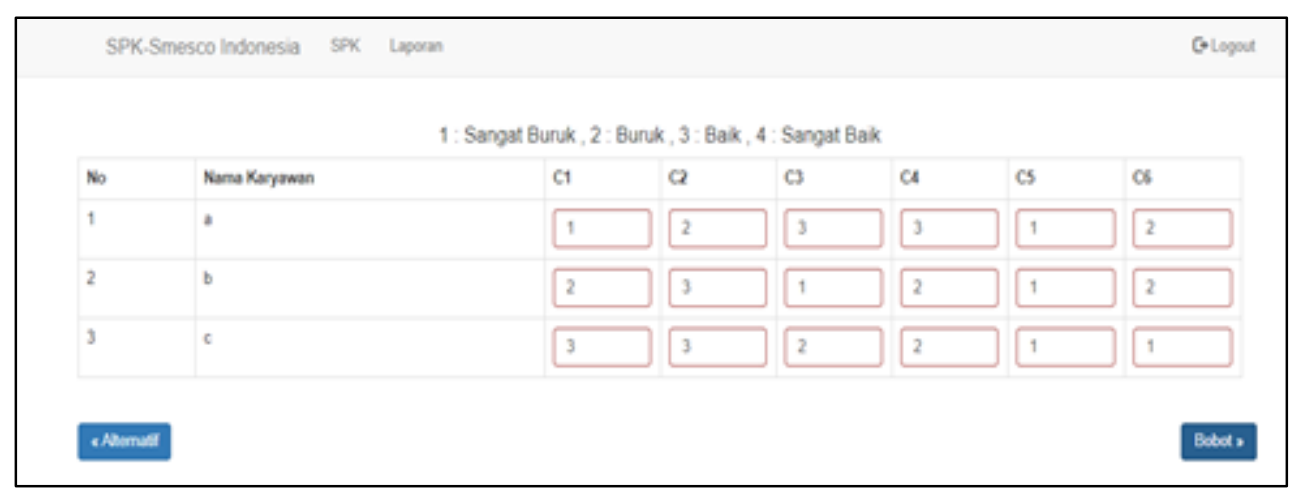

Gambar 6. Tampilan Input Nilai

Halaman Input Bobot yang ditampilkan pada gambar 7 merupakan halaman untuk mengisikan nilai bobot dari masingmasing kriteria penilaian. Setelah mengisikan bobot dari setiap kriteria, klik tombol Matrik R untuk menampilkan bentuk penilaian secara matriks yang ditampilkan pada gambar 8 .

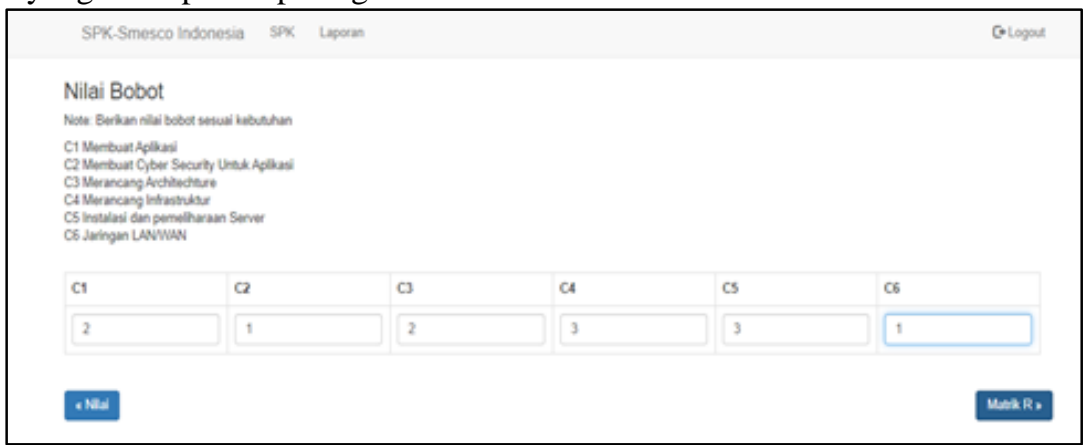

Gambar 7. Tampilan Bobot 
Uji coba dilakukan dengan menggunakan 2 data calon karyawan, dengan menampilkan hasil perhitungan penilaian setiap calon karyawan dalam bentuk Normalisasi Matriks R (1) pada tabel 3.

Tabel 3. Hasil Normalisasi Matriks R

\begin{tabular}{|l|l|l|l|l|}
\hline No & Nama & C1 & C2 & C3 \\
\hline 1 & Aku & 0.7071 & 0.5547 & 0.5547 \\
\hline 2 & Kamu & 0.7071 & 0.532 & 0.532 \\
\hline No & Nama & C4 & C5 & C6 \\
\hline 1 & Aku & 0.5547 & 0.5547 & 0.5547 \\
\hline 2 & Kamu & 0.532 & 0.532 & 0.532 \\
\hline
\end{tabular}

Tabel 4 menampilkan Hasil normalisasi matriks $\mathrm{Y}$ berdasarkan persamaan 2 .

Tabel 4. Hasil Normalisasi Matriks $Y$

\begin{tabular}{|l|l|l|l|l|}
\hline No & Nama & C1 & C2 & C3 \\
\hline 1 & Aku & 1.412 & 1.1094 & 1.1094 \\
\hline 2 & Kamu & 1.412 & 1.664 & 1.664 \\
\hline No & Nama & C4 & C5 & C6 \\
\hline 1 & Aku & 1.1094 & 1.1094 & 1.1094 \\
\hline 2 & Kamu & 1.664 & 1.664 & 1.664 \\
\hline
\end{tabular}

Nilai ideal dihasilkan seperti pada tabel 5, pada setiap kriteria yang terdapat pada penilaian.

Tabel 5. Nilai Ideal

\begin{tabular}{|l|l|l|l|}
\hline Y & C1 & C2 & C3 \\
\hline Positif & 1.412 & 1.664 & 1.664 \\
\hline Negatif & 1.412 & 1.412 & 1.1094 \\
\hline Y & C4 & C5 & C6 \\
\hline Positif & 1.664 & 1.664 & 1.664 \\
\hline Negatif & 1.1094 & 1.1094 & 1.1094 \\
\hline
\end{tabular}

Tabel 6 menghasilkan Jarak Solusi Ideal, yang merupakan jarak alternatif matriks solusi ideal positif/negatif dengan matriks $y$.

Tabel 6 Jarak Solusi Ideal

\begin{tabular}{|l|l|l|l|}
\hline No & Alternatif & Positif & Negatif \\
\hline 1 & Aku & 1.2401 & 0 \\
\hline 2 & Kamu & 0 & 1.2401 \\
\hline
\end{tabular}

Pada tabel 7 menampilkan hasil akhir penilaian calon karyawan berdasarkan rangking

Tabel 7. Hasil Berdasarkan Rangking

\begin{tabular}{|l|l|l|}
\hline Nama & V & Rangking \\
\hline Kamu & 1 & 1 \\
\hline Aku & 0 & 2 \\
\hline
\end{tabular}

\subsection{Uji Coba Sistem Perekrutan Karyawan di SMESCO Indonesia}

Aplikasi ini telah diuji coba dengan melakukan penilaian terhadap 10 orang calon karyawan dengan jumlah kriteria penilaian sebanyak 6 kriteria $(\mathrm{C} 1, \mathrm{C} 2, \mathrm{C} 3, \mathrm{C} 4, \mathrm{C} 5$ dan C6) dapat dilihat pada tabel 8.
Tabel 8. Penilaian 10 Calon Karyawan berdasarkan 6 kriteria

\begin{tabular}{|l|l|l|l|l|l|l|l|}
\hline No & Nama & C1 & C2 & C3 & C4 & C5 & C6 \\
\hline 1 & A & 3 & 2 & 2 & 1 & 1 & 1 \\
\hline 2 & B & 1 & 2 & 4 & 2 & 3 & 1 \\
\hline 3 & C & 2 & 4 & 2 & 2 & 3 & 1 \\
\hline 4 & D & 2 & 4 & 2 & 2 & 2 & 2 \\
\hline 5 & E & 2 & 4 & 4 & 4 & 1 & 1 \\
\hline 6 & F & 4 & 4 & 2 & 2 & 1 & 1 \\
\hline 7 & G & 3 & 3 & 2 & 2 & 3 & 3 \\
\hline 8 & H & 3 & 4 & 2 & 2 & 3 & 2 \\
\hline 9 & I & 2 & 3 & 1 & 1 & 4 & 2 \\
\hline 10 & J & 4 & 1 & 1 & 4 & 4 & 4 \\
\hline
\end{tabular}

Untuk nilai bobot pada 6 kriteria diisikan dengan nilai $\mathrm{C} 1=2, \mathrm{C} 2=3, \mathrm{C} 3=3, \mathrm{C} 4=1, \mathrm{C} 5=1$ dan $\mathrm{C} 6=1$.

Setelah diisikan penilaian terhadap masing-masing kriteria dan bobot dari setiap kriteria, maka dilakukan proses perhitungan hasil normalisasi dalam bentuk matriks $\mathrm{R}$ dan $\mathrm{Y}$ berdasarkan persamaan 1 dan persamaan 2, yang ditampilkan pada tabel 9 dan 10 .

Tabel 9. Hasil normalisasi matriks $\mathbf{R}$

\begin{tabular}{|l|l|l|l|l|}
\hline No & Nama & C1 & C2 & C3 \\
\hline 1 & A & 0.3441 & 0.1933 & 0.2626 \\
\hline 2 & B & 0.1147 & 0.1933 & 0.5252 \\
\hline 3 & C & 0.2294 & 0.3867 & 0.2626 \\
\hline 4 & D & 0.2294 & 0.3867 & 0.2626 \\
\hline 5 & E & 0.2294 & 0.3867 & 0.5252 \\
\hline 6 & F & 0.4566 & 0.3867 & 0.2626 \\
\hline 7 & G & 0.3441 & 0.29 & 0.2626 \\
\hline 8 & H & 0.3441 & 0.3867 & 0.2626 \\
\hline 9 & I & 0.2294 & 0.29 & 0.1313 \\
\hline 10 & J & 0.4588 & 0.0967 & 0.1313 \\
\hline No & Nama & C4 & C5 & C6 \\
\hline 1 & A & 0.1313 & 0.1155 & 0.1543 \\
\hline 2 & B & 0.2626 & 0.3464 & 0.1543 \\
\hline 3 & C & 0.2626 & 0.3464 & 0.1543 \\
\hline 4 & D & 0.2626 & 0.2309 & 0.3066 \\
\hline 5 & E & 0.5252 & 0.1155 & 0.1543 \\
\hline 6 & F & 0.2626 & 0.1155 & 0.1543 \\
\hline 7 & G & 0.2626 & 0.3464 & 0.4629 \\
\hline 8 & H & 0.2626 & 0.3464 & 0.3066 \\
\hline 9 & I & 0.1313 & 0.4619 & 0.3066 \\
\hline 10 & J & 0.5252 & 0.4619 & 0.6172 \\
\hline & & & & \\
\hline
\end{tabular}

Tabel 10. Hasil normalisasi matriks $\mathrm{Y}$

\begin{tabular}{|l|l|l|l|l|}
\hline No & Nama & C1 & C2 & C3 \\
\hline 1 & A & 0.6882 & 0.5799 & 0.7878 \\
\hline 2 & B & 0.2294 & 0.5779 & 1.5756 \\
\hline 3 & C & 0.4588 & 1.1601 & 0.7878 \\
\hline 4 & D & 0.4588 & 1.1601 & 0.7878 \\
\hline 5 & E & 0.4588 & 1.1601 & 1.5756 \\
\hline 6 & F & 0.9176 & 1.1601 & 0.7878 \\
\hline 7 & G & 0.6882 & 0.87 & 0.7878 \\
\hline 8 & H & 0.6882 & 1.1601 & 0.7878 \\
\hline 9 & I & 0.4588 & 0.87 & 0.3939 \\
\hline 10 & J & 0.9176 & 0.2901 & 0.3939 \\
\hline No & Nama & C4 & C5 & C6 \\
\hline 1 & A & 0.1313 & 0.1155 & 0.1543 \\
\hline
\end{tabular}




\begin{tabular}{|l|l|l|l|l|}
\hline 2 & B & 0.2626 & 0.3464 & 0.1543 \\
\hline 3 & C & 0.2626 & 0.3464 & 0.1543 \\
\hline 4 & D & 0.2626 & 0.2309 & 0.3066 \\
\hline 5 & E & 0.5252 & 0.1155 & 0.1543 \\
\hline 6 & F & 0.2626 & 0.1155 & 0.1543 \\
\hline 7 & G & 0.2626 & 0.3464 & 0.4629 \\
\hline 8 & H & 0.2626 & 0.3464 & 0.3066 \\
\hline 9 & I & 0.1313 & 0.4619 & 0.3066 \\
\hline 10 & J & 0.5252 & 0.4619 & 0.6172 \\
\hline
\end{tabular}

Setelah dihasilkan normalisasi matriks $\mathrm{R}$ dan $\mathrm{Y}$, selanjutnya dilakukan perhitungan Nilai Ideal Positif dan Negatif berdasarkan persamaan 3 dan persamaan 4 dapat dilihat pada tabel 11 .

Tabel 11. Nilai Ideal

\begin{tabular}{|l|l|l|l|}
\hline Y & C1 & C2 & C3 \\
\hline Positif & 0.9176 & 1.1601 & 1.5756 \\
\hline Negatif & 0.2294 & 0.2901 & 0.3939 \\
\hline Y & C4 & C5 & C6 \\
\hline Positif & 0.5252 & 0.4819 & 0.5172 \\
\hline Negatif & 0.1313 & 0.1155 & 0.1543 \\
\hline
\end{tabular}

Serta dilakukan perhitungan Jarak Solusi Ideal , dapat dilihat pada tabel 12 .

Tabel 12. Jarak Solusi Ideal

\begin{tabular}{|c|c|c|c|}
\hline No & Alternatif & Positif & Negatif \\
\hline 1 & A & 1.2246 & 0.6706 \\
\hline 2 & B & 1.0521 & 1.2454 \\
\hline 3 & $\mathrm{C}$ & 1.0691 & 1.0175 \\
\hline 4 & $\mathrm{D}$ & 1.0241 & 1.0095 \\
\hline 5 & $\mathrm{E}$ & 0.7361 & 1.5366 \\
\hline 6 & $\mathrm{~F}$ & 1.0119 & 1.1844 \\
\hline 7 & $\mathrm{G}$ & 0.9293 & 0.9315 \\
\hline 8 & $\mathrm{H}$ & 0.9224 & 1.1031 \\
\hline 9 & I & 1.3934 & 0.7299 \\
\hline 10 & $\mathrm{~J}$ & 1.4674 & 0.9813 \\
\hline No & Alternatif & Positif & Negatif \\
\hline 1 & A & 1.2246 & 0.6706 \\
\hline 2 & B & 1.0521 & 1.2454 \\
\hline 3 & $\mathrm{C}$ & 1.0691 & 1.0175 \\
\hline 4 & $\mathrm{D}$ & 1.0241 & 1.0095 \\
\hline 5 & $\mathrm{E}$ & 0.7361 & 1.5366 \\
\hline 6 & $\mathrm{~F}$ & 1.0119 & 1.1844 \\
\hline 7 & $\mathrm{G}$ & 0.9293 & 0.9315 \\
\hline 8 & $\mathrm{H}$ & 0.9224 & 1.1031 \\
\hline 9 & I & 1.3934 & 0.7299 \\
\hline 10 & $\mathrm{~J}$ & 1.4674 & 0.9813 \\
\hline
\end{tabular}

Langkah selanjutnya adalah melakukan perhitungan nilai preferensi (V) dan pemeringkatan, hasilnya dapat dilihat pada tabel 13 .

Tabel 13. Hasil Berdasarkan Rangking

\begin{tabular}{|l|l|l|}
\hline Nama & V & Rangking \\
\hline E & 0.6755 & 1 \\
\hline H & 0.5446 & 2 \\
\hline B & 0.5421 & 3 \\
\hline F & 0.5393 & 4 \\
\hline G & 0.5006 & 5 \\
\hline D & 0.4964 & 6 \\
\hline C & 0.4893 & 7 \\
\hline J & 0.4007 & 8 \\
\hline A & 0.3539 & 9 \\
\hline I & 0.3436 & 10 \\
\hline
\end{tabular}

Data yang telah diisi lalu dihitung sesuai dengan perhitungan metode TOPSIS dan dihasilkan bahwa calon karyawan dengan nama E memiliki nilai alternatif terbaik dari 10 calon karyawan yang dilakukan penilaian.

\section{KESIMPULAN}

Pembuatan Aplikasi Decision Support Systems (DSS) dalam menentukan calon karyawan pada SMESCO Indonesia dengan Metode TOPSIS berbasiskan web, telah berhasil diimplementasikan. Dalam aplikasi ini setiap calon karyawan dinilai berdasarkan kriteria yang telah ditentukan oleh perusahaan. Setiap kriteria tersebut memiliki nilai bobot masing-masing, sehingga dalam mengambil keputusan setiap calon karyawan mendapat laporan penilaian yang detail dan transparan, bersifat online dan realtime, serta HRD mendapatkan penilaian karyawan yang objektif sesuai dengan bobot kriteria yang ditentukan.

\section{SARAN}

Pembuatan Aplikasi Decision Support Systems (DSS) mengenai perekrutan calon karyawan dapat dikembangkan dengan membandingkan hasil penilaian metode TOPSIS dengan beberapa metode DSS lainnya, seperti AHP (Analitical Hierarcy Process) dan SAW (Simple Additive Weighting). Sehingga akan diketahui metode yang lebih objektif dan ideal terhadap sistem penunjang keputusan.

\section{DAFTAR PUSTAKA}

Fristy, R., 2017, Sistem Pendukung Keputusan Menggunakan Metode Topsis Dalam Memilih Kepala Departemen Pada Kantor Balai Wilayah Sungai Sumatera II Medan, Journal Of Informatic Pelita Nusantara, Vol. 2, No 1, e-ISSN 2541-3724.

Gregorius, R \& E., 2013, Analisis Penggabungan Metode SAW dan metode TOPSIS untuk mendukung keputusan seleksi penerimaan dosen, Thesis (S2), http://e-journal.uajy.ac.id/id/eprint/4360. 
Harpad, B dan Salmon, S., 2018, Penerapan Metode AHP dan Metode TOPSIS Dalam Sistem Pendukung Keputusan Pemilihan Asisten Laboratorium Komputer Pada STMIK Widya Cipta Darma Samarinda, Jurnal SEBATIK Vol. 19, No. 1, ISSN : $1410-3737$

Irfan, Subakti., 2012, Decision Support System (DSS), Institute Teknologi Sepuluh Nopember (ITS).

Irvan, M., 2017, Penerapan Metode TOPSIS Untuk Sistem Pendukung Keputusan Penentuan Keluarga Miskin Pada Desa Panca Karsa II, ILKOM, Jurnal Ilmiah Vol. 9, No.3, ISSN 2087-1716.

Kusumadewi, 2006, Technique for Order Preference by Similarity to Ideal Solution (TOPSIS). Yogyakarta: Graha Ilmu.

Karmila, 2017, Sistem Pendukung Keputusan dalam Merekomendasikan Smartphone untuk Kalangan Pemula dengan Metode TOPSIS, Seminar Nasional Multidisplin Ilmu, OSF, https://osf.io/5n6qd/

Putri, A., 2018, Sistem Pendukung Keputusan Penentuan Lokasi Wisata Dengan Metode TOPSIS, Jurnal Teknologi Informasi dan Ilmu Komputer (JTIIK), Vol. 5, No. 5, 621-628.

Satriawaty, M., 2015, Sistem Pendukung Keputusan Penentuan Karyawan Kontrak Menjadi Karyawan Tetap Menggunakan Metode TOPSIS, Jurnal Ilmiah Teknologi Informasi Terapan, Vol. I, No. 2.

Sriani, S dan Putri, RA., 2018, Analisa Sistem Pendukung Keputusan Menggunakan Metode TOPSIS Untuk Sistem Penerimaan Pegawai Pada SMA AlWashliyah Tanjung Morawa, Jurnal Ilmu Komputer dan Informatika, Vol. 01, No. 01, ISSN 25998-6341

Sunalia, A., 2017, Sistem Pendukung Keputusan Penentuan Penerimaan Beasiswa Pada SMK Madyatama Dengan Metode TOPSIS, Seminar Hasil Penelitian Ilmu Komputer Ke-2 (SENTIKOM2017), hal. 013-018. 